\title{
Affinity maturation of antibodies in the course of humoral immune response
}

\author{
S.A. Bobrovnik, M.A. Demchenko \\ Palladin Institute of Biochemistry NAS of Ukraine \\ 9 Leontovicha Street, Kyiv, 01601, Ukraine \\ sab@biochem.kiev.ua
}

\begin{abstract}
The process of affinity maturation in the course of humoral immune response of $B A L B / c$ mice against horse muscle myoglobin was studied. For this purpose we used the method of determination of the affinity constants for high-and low-affinity antibodies, present in the mixture. Application of this method allowed us to determine the main characteristics of humoral immune response change in the course of the immune response against T-dependent protein antigen. It was shown that the affinity of antibodies, their quantity, and the proportion of high-affinity specific antibodies gradually increased during immune response development.
\end{abstract}

Keywords: affinity, affinity maturation, non-linear regression

Introduction. The development of immune response to various protein antigens is known to result in the change in the affinity of antibodies, which is higher at later stages of immune response compared to its initial stages [1-5]. Reverse effect may take place only in case of some disorders in the development of immune response, in the course of some diseases or when the organism is immunized with extremely high dosages of antigen, which leads to exhaustion of corresponding clones of high-affinity B-lymphocytes. In other cases the affinity of antibodies increases, especially after repeated immunizations.

It is noteworthy that determination of affinity of antibodies in blood serum, containing a great number of clones of similar specificity but different affinity, is a difficult task. In most cases the use of current investigation methods allows defining only the average value, which does not show the exact amount and type

(C) S.A. BOBROVNIK, M.A. DEMCHENKO, 2008 of antibodies (high- or low-affinity), present in the investigated mixture. For instance, the method, suggested in [6], and its modification, described by Stevens in [7], allow accurate determination of the affinity of only one clone of bivalent antibodies, using ELISA. In case if the investigated mixture contains two or more kinds of antibodies, including high- and low-affinity ones, the result of determining affinity depends significantly on the ratio of each kind of these antibodies as well as on the range of concentrations of competing antigen, used in the experiment [8-11].

The aim of current work was to determine affinity of two kinds of antibodies, present in the mixture, and to find the correlation between the amounts of high- and low-affinity antibodies in investigated samples. It allowed us to set the task of quantitative estimation of parameters, reflecting the process of development of immune response to protein antigen, which results in maturation of affinity of antibodies and change in the 
ratio of concentrations of high- and low-affinity antibodies.

Theory. To determine the affinity of one kind of antibodies using ELISA, Friguet et al. [6] elaborated the method which gained wide popularity due to the simplicity of its application and accuracy of obtained data. The authors showed that in case of excess in competing antigen in the antigen-antibody mixture, there is a linear dependency between the ratio of total amount of antibodies to the amount of antibodies, blocked by antigen, and the reverse concentration of antigen

$$
\frac{A_{0}}{A_{0}-A_{i}}=1+\frac{K_{d}}{l_{i}}
$$

where $K_{d}$ - dissociation constant, i.e. value, inverse to the value of affinity; $A_{0}$ - staining of cells in the absence of antigen; $A_{i}$ - staining of cells in the presence of competing antigen, whose concentration equals $l_{i}$.

The diagram of this dependency is a straight line with the slope, which is equal to the value of affinity constant. Therefore, this diagram allows determining affinity of interaction of antibodies and antigen.

Later Stevens [7] voiced an opinion that equation (1), suggested by Friguet et al., can be related only to univalent antibodies, while to consider bivalent antibodies, one should define the square root of the left side of equation (1), so the proper equation will be

$$
\sqrt{\frac{A_{0}}{A_{0}-A_{i}}}=1+\frac{K_{d}}{l_{i}} .
$$

We have obtained equation (2) strictly mathematically which proved $[8,9]$ the correctness of Stevens' remark [7]. Theoretical calculations (Fig.1, a) and experimental data evidence to the correctness of equation (2) as well.

At the same time, in case if the investigated sample of antibodies contains two kinds of antibodies of similar specificity, and their affinity differs considerable, the diagram will present non-linear dependency in the form of a convex curve instead of linear dependency between the values of $\sqrt{\frac{A_{0}}{A_{0}-A_{i}}}$ and $1 / l_{i}$, presented by a straight line (Fig.1, $b$ ). To determine affinity of both kinds of antibodies and the ratio between their amounts in the investigated sample, we suggested new coordinates, where presentation of data on the amount of free antibodies in the mixture with different concentrations of competing antigen is shown in the form of concave curve (Fig.2, a). The solution of these equations, and thus, the determination of quantitative values of parameters under question, i.e. values of $K_{1}$ and $K_{2}, A_{1}$ and $A_{2}$ [8-10] becomes possible after finding the slope angles of asymptotes to this curve, as well as cross-points of asymptotes with axes of coordinates, and introducing the found values into suggested four equations.

The drawback of the mentioned method is the use of a wide range of concentrations of the competing antigen with the purpose of increasing the accuracy of determination of required characteristics of the mixture of antibodies. Only sufficient range of concentrations of antigen allows drawing experimental curves of binding which are rather close to axes of coordinates and thus allow obtaining sufficiently accurate required values of the affinity of both kinds of antibodies and the ratio of their concentrations. Unfortunately, these experiments are technically complicated, and the accuracy of determination decreases significantly when one defines staining of cells with very low intensity.

Therefore, we have suggested a new method [11, 12], which is rather simple, yet allows obtaining more accurate data concerning the affinity of two kinds of antibodies and the ratio of their amounts in samples. It is based on the method of non-linear regression for calculation of parameters of the curve of binding using the known equation due to modern methods of computational mathematics, e.g. Origin 75 software.

We have shown previously that the dependency of intensity of staining of wells $A_{i}$, defined with ELISA (in case if staining of wells is proportional to the concentration of free antibodies in the antigen-antibody mixture) on the concentration of competing antigen $l_{i}$ can be presented by the following equation (Fig.2, $b$ ):

$$
A_{i}=\frac{A_{1}\left(1+2 l_{i} K_{1}\right)}{\left(1+l_{i} K_{1}\right)^{2}}+\frac{A_{2}\left(1+2 l_{i} K_{2}\right)}{\left(1+l_{i} K_{2}\right)^{2}},
$$

where $K_{1}$ and $K_{2}$ - affinity constants of both kinds of antibodies; $A_{1}$ and $A_{2}$ - staining of wells, which would be obtained in case of using each kind of antibodies separately in the absence of competing antigen. 

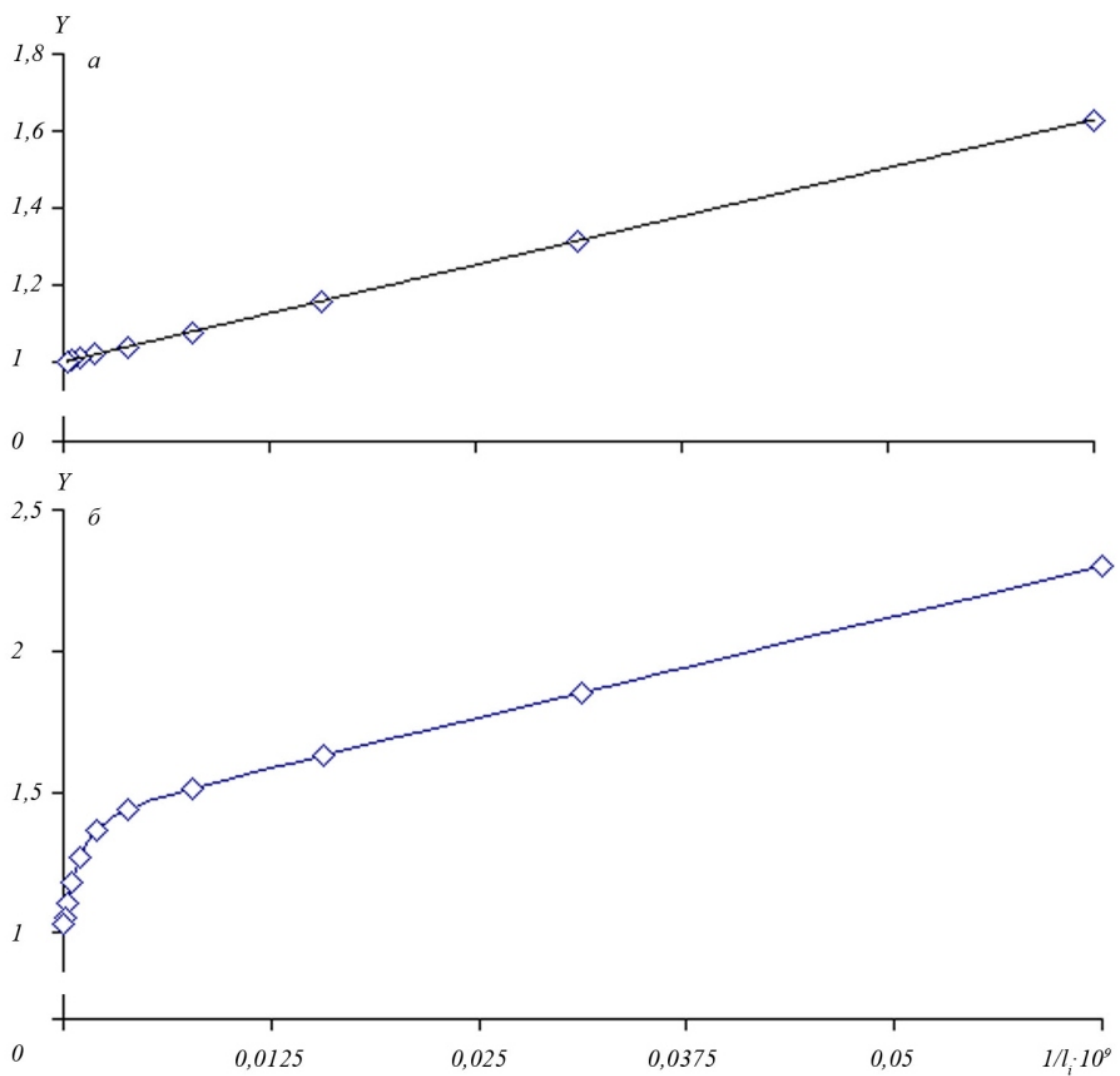

Fig. 1 Theoretical curves of antigen binding by bivalent antibodies, presented in coordinates $\mathrm{Y}==\sqrt{\frac{A_{0}}{A_{0}-A_{i}}}$ against $\mathrm{l} / l_{i}: a-$ linear dependency between values of $\sqrt{\frac{A_{0}}{A_{0}-A_{i}}}$ and $1 / l_{i}$ for one kind of antibodies with the affinity constant $\mathrm{K}=1.0 \cdot 10^{8} \mathrm{M}^{-1} ; b$ - non-linear dependency between the values of $\sqrt{\frac{A_{0}}{A_{0}-A_{i}}}$ and $1 / l_{i}$ for two kinds of antibodies in equal concentrations with the affinity constants $K_{1}=1,0 \cdot 10^{8} \mathrm{M}^{-1}$ и $K_{2}=$ $=1,0 \cdot 10^{6} \mathrm{M}^{-1}$
Having found values of $A_{1}$ at different known values of competing antigen $l_{i}$ via experiment, it is possible to apply the method of non-linear regression to find the values of $K_{1}$ and $K_{2}$, as well as $A_{1}$ and $A_{2}$ which would correspond to experimental curve for its coincidence to the curve, presented by equation (3) in the best possible way. Since values of $A_{1}$ and $A_{2}$ are proportional to the concentration of each of antibodies in the mixture, it is possible to not only define the affinity of both antibodies $K_{1}$ and $K_{2}$ but also to find the ratio of concentrations of these antibodies, which is equal to the ratio of $A_{1}$ to $A_{2}$, or a part of each kind of antibodies, which equals $A_{1} /\left(A_{1}+A_{2}\right)$ and $A_{2}\left(A_{1}+A_{2}\right)$.

Materials and Methods. Horse muscle myoglobin was used as antigen (Sigma, USA). Six mice of $\mathrm{BALB} / \mathrm{c}$ line (female mice, weight about 22-25 gram) were immunized intravenously with $250 \mu \mathrm{g}$ /per mouse of myoglobin, diluted in the physiological solution. Immunization was performed with the similar dose of mentioned antigen three times, with the interval of three weeks. In 10 days after each immunization approximately $250 \mu \mathrm{l}$ of blood were taken from the tail veins of mice to obtain serum. Sera of three mice were combined in two pools, consisting of three separate sera. Antisera to myoglobin, obtained by the aforementioned method, were frozen.

Myoglobin was sorbed on 96-cell Mai Sorp plates (Nunc, Denmark), via incubating $110 \mu \mathrm{l} /$ cell of myoglobin solution $(30 \mu \mathrm{g} / \mathrm{ml}$ in $0.1 \%$ solution of ammonium bicarbonate, $\mathrm{pH} 8.5$ ) in plates at $4{ }^{\circ} \mathrm{C}$ for 18 hours. Prior to using plates were thoroughly washed of non-bound myoglobin, and introduced with $100 \mu \mathrm{l} /$ cell of investigated mixture, consisting of diluted antiserum and some amount of myoglobin. Plates were incubated with investigated samples of antisera and antigen for 45-50 min at constant shaking, then the solutions were removed from the cells and plates were washed with running water. ELISA was applied to determine the amount of antibodies of IgG class, bound to myoglobin, sorbed on the plate, i.e. we determined the amount of antibodies, one or two paratopes of which were not occupied by the soluble antigen.

To determine the dilution of antisera, optimal for the determination of affinity of antibodies by 


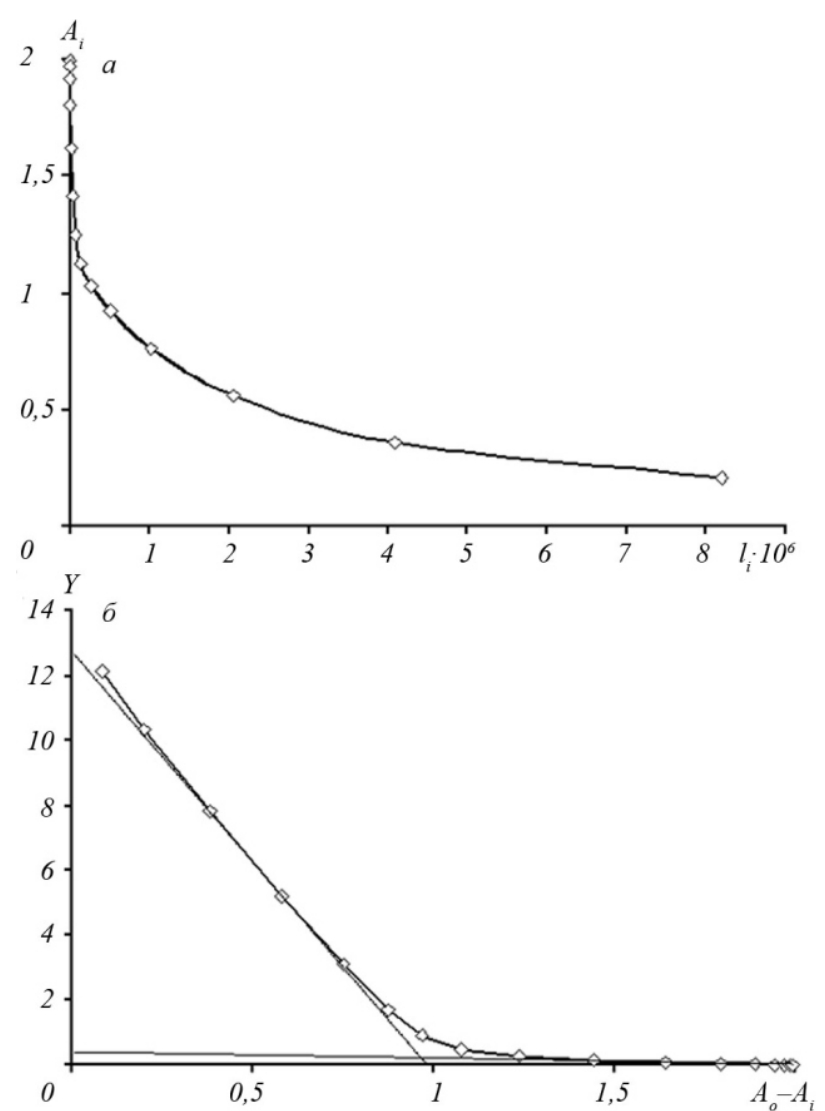

Fig.2 Non-linear dependency of the amount of free antibodies (i.e. antibodies, one or two paratopes of which are not blocked by antigen), present in the mixture with antigen in equilibrium, on the concentration of antigen $(a)$ and the same dependency in the coordinates $Y=\frac{A_{0}-A_{i}+\sqrt{A_{0}\left(A_{0}-A_{i}\right)}}{l_{i}} \cdot 10^{-7}$ against the value $A_{0}-A_{i}$

(b). Both theoretical curves are calculated for the following parameters of antigen-antibody interaction: $\mathrm{K}_{1}=1.0 \cdot 10^{8} \mathrm{M}^{-1} ; \mathrm{K}_{2}=$ $1.0 \cdot 10^{6} \mathrm{M}^{-1}$; range of antigen concentrations $l_{i}=1.0 \cdot 10^{-9}-2.62 \cdot 10^{-4}$ $\mathrm{M}, A_{1}=1.0 ; A_{2}=1.0 ; A_{0}=A_{1}+A_{2}$

mentioned methods, sera were titrated in $0.2 \%$ solution of BSA in buffered physiological solution, containing $0.1 \%$ twin-20 (TBF). Dilutions of antiserum, providing directly proportional decrease in the intensity of cell staining at the decrease in antiserum concentration, were further used in the experiments of determining the affinity of antibodies [6].

Aliquots of $0.2 \mathrm{ml}$ of $(1: 50)-(1: 150)$ times diluted antisera (according to the data of the preliminary experiment of titration) were 1:1 mixed with the solutions of myoglobin of different concentration (from $2.5 \cdot 10^{-7}$ to $6.4 \cdot 10^{-5} \mathrm{M}$ ) in $0.2 \%$ solution of BSA in TBF. Samples were incubated at room temperature for 18 hours, then $0.1 \mathrm{ml}$ of each sample of mixture (in three replications) were introduced into the wells of immunological plates with sorbed myoglobin, plates were incubated with these samples for 45-50 min at constant shaking, then samples were removed from the wells, plates were washed and the relative amount of bound antibodies was determined using ELISA. The values of staining intensity for each sample were defined via calculation of the average value from three measurements.

Method of non-linear regression was used to determine the values of $K_{1}, K_{2}, A_{1}$, and $A_{2}$, then the ratios $A_{1} /\left(A_{1}+A_{2}\right)$ and $A_{2} /\left(A_{1}+A_{2}\right)$ were calculated i.e. the ratio of concentrations of high- and low-affinity antibodies in the investigated mixture was found.

Results and Discussion. Fig. $3, a$ presents the results of titration of antisera to myoglobin with ELISA, obtained after one-, two-, and three-time intravenous immunization of mice with myoglobin. Dilution in more than 50 times leads to the occurrence of linear dependencies between the concentration of antiserum and intensity of well staining. At the same time concentration of IgG antibodies in antiserum after two-times immunization is approximately 1.5 times higher compared to that after one-time immunization, and the concentration of antibodies after three-times immunization is approximately 2 times higher compared to that after two-times immunization. Therefore, to determine affinity of IgG antibodies, antisera were diluted 50, 75, and 150 times to get approximately equal concentrations of antibodies in the obtained samples.

Fig. $3, b$ shows results evidencing to the dependence of the amount of free $\mathrm{IgG}$ antibodies in the mixture with antigen on the concentration of antigen. Since each of the curves, presented in this Figure, is described with equation (3), application of Origin 75 software allows determining values of $K_{1}, K_{2}, A_{1}$, and $A_{2}$, the most appropriate to the adjustment of obtained experimental data to the theoretical curve, described by equation (3). The required values are presented in Table.

The data of Table demonstrate that experiments proved gradual increase in the affinity of forming IgG antibodies in the process of development of immune response to $\mathrm{T}$-dependent protein antigens. This pattern is not surprising, since affinity maturation of immune response is known to include first switching synthesis 


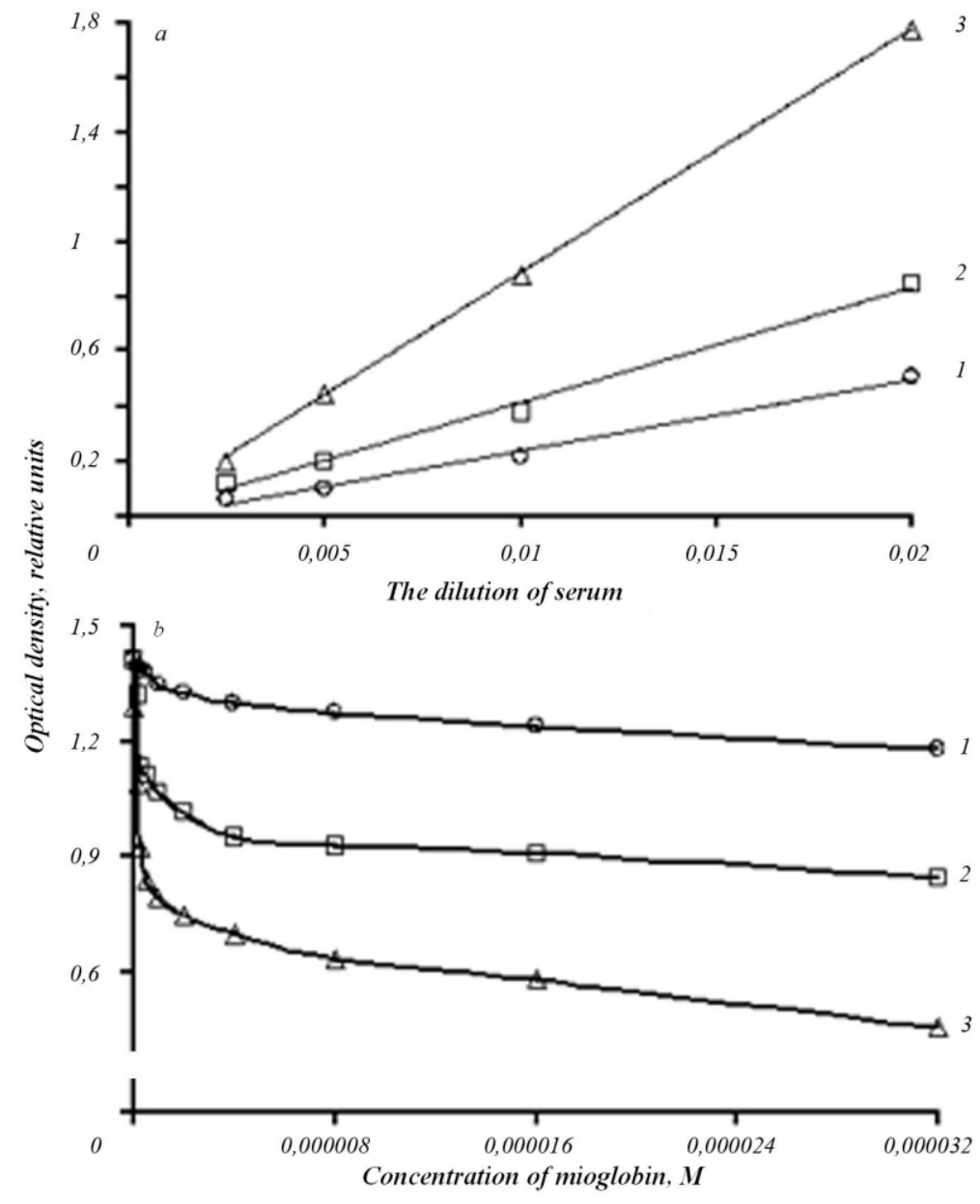

Fig.3 Experimental curves of dependency of free $\operatorname{IgG}$ antibodies to myoglobin on the dilution of serum or on concentration of myoglobin in the mixture with antibodies: $a$ - influence of dilution of antisera to myoglobin on the amount of antibodies, bound to myoglobin, which was sorbed on the immunological plate ( 1 - one-time; 2 - two-time; 3 - three-time); $b-$ effect of myoglobin concentration in the mixture with antisera to myoglobin on the amount of antibodies in the myoglobin-antiserum mixture, where one or two paratopes are not bound to myoglobin and are free (1 one-time; 2 - two-time; 3 -three-time) of antibodies from IgM class to IgG [8], then gradual selection of clones of B-lymphocytes, producing antibodies with higher affinity [2-5, 13, 14].

This process, called maturation of affinity of antibodies, consists of both somatic mutations, responsible for the structure of recognition centre of antibody, and subsequent selection of clones, producing antibod $\mathrm{e}_{\mathrm{e}}$ with higher affinity $[5,15-18]$. Therefore this process is considered to resemble evolution according to Darwin, since the first stage is mutation of the corresponding gene, and the second one is selection of clones with the most advantageous mutations [19].

It should be noted that application of suggested method allows not only determining the tendency towards increase in similarity between antibodies and antigen in the process of immune response, but also to track the dynamics of appearing of antibodies with higher affinity as well as ratio of their amount to low-affinity antibodies. Table demonstrates that in 10 days after one-time immunization of horse muscle myoglobin sera of mice has only about $10 \%$ of relatively high-affinity antibodies $\left(K_{1}=1.62 \cdot 10^{6} \mathrm{M}^{-1}\right)$ and about $90 \%$ - of low-affinity antibodies $\left(K_{2}=\right.$ $\left.1.17 \cdot 10^{4} \mathrm{M}^{-1}\right)$.

After repeated immunization of mice with myoglobin the amount of high-affinity antibodies is one third of all antibodies, and the affinity of these high-affinity antibodies increases to $8.74 \cdot 10^{6} \mathrm{M}^{-1}$, i.e. exceeds that of high-affinity antibodies after one-time immunization about 5 times. The affinity of low-affinity antibodies $\left(K_{1}=1.62 \cdot 10^{6} \mathrm{M}^{-1}\right)$ is also higher compared to the first immunization though in this case the difference is only about 1.5 times.

Finally, after the third immunization the ratio of high-affinity antibodies increases even more and is 
Values of affinity constants of high-and low-affinity antibodies to myoglobin in sera of BALB/c mice in 10 days after intravenous immunization of mice with horse muscle myoglobin

\begin{tabular}{c|c|c|c|c}
\hline Immunization & $K_{1}$ & $K_{2}$ & $A_{1} /\left(A_{1}+A_{2}\right), \%$ & $A_{2} /\left(A_{1}+A_{2}\right), \%$ \\
\hline One-time & $\begin{array}{c}1,62 \cdot 10^{6} \\
\left( \pm 3,22 \cdot 10^{5}\right)\end{array}$ & $\begin{array}{c}1,17 \cdot 10^{4} \\
\left( \pm 9,49 \cdot 10^{2}\right)\end{array}$ & 9,9 & 90,1 \\
Two-time & $8,74-10^{6}$ & $1,62 \cdot 10^{4}$ & & 66,7 \\
& $\left( \pm 2,17 \cdot 10^{6}\right)$ & $\left( \pm 4,71 \cdot 10^{3}\right)$ & 33,3 & 53,5 \\
Three-time & $1,23 \cdot 10^{7}$ & $4,49 \cdot 10^{4}$ & 46,5 & \\
& $\left( \pm 1,37 \cdot 10^{6}\right)$ & $\left( \pm 4,68 \cdot 10^{3}\right)$ & &
\end{tabular}

close to $50 \%$. Their affinity $\left(K_{1}=1.23 \cdot 10^{7} \mathrm{M}^{-1}\right)$ is also higher compared to the affinity of antibodies after two-times immunization. Low-affinity antibodies after three-time immunization $\left(K_{2}=4.49 \cdot 10^{4} \mathrm{M}^{-1}\right)$ have approximately three times higher affinity to myoglobin compared to similar antibodies after two-times immunization. Therefore, the process of development of immune response is characterized not only by the increase in the ratio of high-affinity antibodies compared to low-affinity antibodies, but also by the increase in absolute values of affinity of pools of both high-affinity and low-affinity antibodies.

It is evident that results obtained are in complete agreement with numerous data $[1-5,13-20]$ concerning gradual qualitative change in characteristics of produced antibodies in response to repeated immunization of the organism with foreign protein antigen. Besides, the use of elaborated method of estimating affinity of high- and low-affinity antibodies, present in the mixture, allowed obtaining quantitative characteristics of this process. The data of Fig.3, $a$, proving the increase in total amount of myoglobin-specific antibodies, which appear in blood flow in the process of immune response to intravenous immunizations with myoglobin, as well as obtained additional data on the characteristic of produced antibodies allow explaining the events in the course of development of humoral immune response to protein antigens.

The results of our investigation evidence to the importance of determining both the affinity of not less than two kinds of antibodies of the same specificity in case of their presence in the mixture, and the ratio between concentrations of these antibodies. Current work testifies to the significance of elaborated method of estimating the affinity of high- and low-affinity antibodies, present in the mixture in unknown proportions.

\section{С. А. Бобровник, М. А. Демченко}

Изменение аффинности антител в ходе развития гуморального иммунного ответа

Резюме

Изучали проиесс аффинного созревания антител в ходе развития гуморального иммунного ответа у мымей $B A L B / c$ на введение миоглобина мышиы лошади. Для проведения этих исследований использован новый метод определения аффинности высоко- и низкоаффинных антител, присутствующих в смеси. Применение этого метода позволило получить основные характеристики гуморального иммунного ответа в ходе его развития на Т-зависимый белковый антиген. Установлено, что аффинность антител, их количество, а также доля высокоаффинных специфических антител постепенно возрастают в проиессе развития иммунного ответа.

Ключевые слова: аффинитет, аффинное созревание, нелинейная регрессия.

\section{REFERENCES}

1. Ройт A. Основы иммунологии.- М.: Мир, 1991.- 327 с.

2. Azur Z., Mazor G., Meilijson I. Maturation of the humoral immune response as an optimization problem // Proc. Biol. Sci.-1991.-245.-P. 147-150.

3. MacLennan I. C., Liu Y. J., Johnson G. D. Maturation and dispersal of B-cell clones during $\mathrm{T}$ cell-dependent antibody responses // Immunol. Rev.-1992.-126.-P. 143-461.

4. Forsdyke D. R. The origins of the clonal selection theory of immunity as a case study for evaluation in science // FASEB J.-1995.-9.-P. 164-166.

5. Kelsoe G. Life and death in germinal centers (redu) // Immunity.-1996.-4.-P. 107-111.

6. Friguet B., Chaffotte A. F., Djavadi-Ohaniance L., Goldberg $M$. E. Measurements of the true affinity constant in solution of antigen-antibody complexes by enzyme-linked 
immunosorbent assay // J. Immunol. Meth.-1985.-77.P. 305-319.

7. Stevens F. J. A modification of an ELISA-based procedure for affinity determination: correction necessary for use with bivalent antibody // Mol. Immunol.-1987.-24.-P. 10551060 .

8. Бобровник C. A. Определение аффинности антител с помощью ELISA // Укр. биохим. журн.-1999.-71, № 6.C. $90-102$.

9. Bobrovnik S. A. ELISA-based method for determining the affinity of bivalent antibodies of two specificities in a miture // Ukr. biokhem. zh.-2000.-72, N 3.-P. 133-141.

10. Bobrovnik $S$. A. Determination of antibody affinity by ELISA. Theory // J. Biochem. and Biophys. Meth.-2003.57.-P. 213-236.

11. Бобровник C. А. Определение аффинности высоко- и низко-аффинных антител, находящихся в смеси, при помощи ELISA и метода нелинейной регрессии // Укр. биохим. журн.-2005.-77, № 3.-С. 155-161.

12. Bobrovnik S. A., Stevens F. J. Deconvolution of antibody affinities and concentrations by non-linear regression analysis of competitive ELISA data // J. Immunol. Meth.2007.-328.-P. 53-58.

13. Cauerhff A., Goldbaum F. A., Braden B. C. Structural mechanism for affinity maturation of an anti-lysozyme antibody // Proc. Nat. Acad. Sci. USA.-2004.-101.-P. 35393544 .
14.Adams C. L., MacLeod M. K. L., Milner-White E. J., Aitken R., Garside P., Scott D. I. Complete analysis of the B-cell response to a protein antigen, from in vivo germinal centre formation to 3-D modelling of affinity maturation // Immunology.-2003.-108.-P. 274-287.

15.Celada F., Seiden $P$. E. Affinity maturation and hypermutation in a simulation of the humoral immune response // Eur. J. Immunol.-1996.-26.-P.1350-1358.

16. Maclennan I. C. M. Germinal centre// Annu. Rev. Immunol.1994.-12.-P. 117-139.

17. Berek C., Berger A., Apel M. Maturation of the immune response in germinal centres // Cell.-1991.-67.-P. 11211129.

18. Neuberger M. S., Milstein C. Somatic hypermutation // Curr. Opin. Immunol.-1995.-7.-P. 248-254.

19. Kelsoe G. V(D)J hypermutation and receptor revision: coloring outside the lines // Curr. Opin. Immunol.-1999.11.-P. 70-75.

20. Furukawa K., Akasako-Furukawa A., Shirai H., Nakamura $H$., Azuma $T$. Junctional amino acids determine the maturation pathway of an antibody // Immunity.-1999.-11.P. 329-338. 